\title{
Does persistence make you healthy? An empirical study on female entrepreneurs from China
}

Heqi Jia ${ }^{1}$, Zhengda $\mathrm{Xu}^{2^{*}}$, Song Lin ${ }^{1}$ and Feng Jiang ${ }^{1}$

\begin{abstract}
Background: Nowadays, more and more women are engaging in entrepreneurial activities. Meanwhile, female entrepreneurs' health problems have been increasingly reported worldwide. What factors would influence female entrepreneurs' health are the subject of this paper.

Methods: This paper focuses on the effects of entrepreneurial experience and age of firm on female entrepreneurs' health through the analysis of 2 years of tracking data in the Bohai Economic Rim, which is one of the most developed areas for entrepreneurial activities in China.

Results: Results from the samples of female entrepreneurs demonstrate that increasing entrepreneurial experience and growing firm age could help female entrepreneurs to activate multiple positive identities. These identities can help female entrepreneurs cope with gender stereotype threat and maintain good health.

Conclusion: This paper contributes to entrepreneur health research in two aspects. First, this study focused on entrepreneurial history indexed by entrepreneurial experience and firm age, enriching the field of female entrepreneurship. Second, this study further explored the mechanism that women cope with stereotype threat in the context of entrepreneurship. At the same time, this paper addresses ways that policy-makers and social media are responsible to help female entrepreneurs stay healthy.
\end{abstract}

Keywords: Female entrepreneur, Health, Entrepreneurial experience, Firm age

\section{Background}

Nowadays, more and more women are engaging in entrepreneurial activities, resulting in similar amounts of female and male entrepreneurs. Meanwhile, female entrepreneurs' health problems have been increasingly reported worldwide. For example, Liu Qing, the president of DiDi (Chinese version of Uber), a famous female leader in China, was diagnosed with breast cancer which was highly associated with entrepreneurial stress in

${ }^{*}$ Correspondence: xuzhengda@btbu.edu.cn

2 Business School, Beijing Technology and Business University,

Beijing 100048, China

Full list of author information is available at the end of the article
2015. ${ }^{1}$ In addition, the founder of Kate Spade suicided due to the bipolar disorder in $2018 .^{2}$ We have to notice that female entrepreneurs are facing severe health problems during the Covid-19 pandemic. BDC (Business Development Company) reported that female entrepreneurs $(51 \%)$ were suffering more depression than male entrepreneurs (40\%) under the pandemic context. ${ }^{3}$

When a novel virus (Covid-19) outbreak in 2019, the economy and society face great uncertainty [1]. 
The ventures were forced to close down to avoid virus spread. It influenced the firm's general operation, such as production and sales [2]. The cash flow of many ventures was facing severe challenges [1]. Entrepreneurs also suffer great psychological distress due to the uncertainty and unpredictable economic environment, especially for female entrepreneurs [3]. Keeping good health is beneficial to female's quality of life during the Covid-19 pandemic [4]. However, the health problems of female entrepreneurs have been largely ignored in empirical studies. Finding what factors would influence female entrepreneurs' health is a significant topic to help them overcome the tough times' challenges. It is also the subject of this article under the pandemic context.

The study of entrepreneurial health has become a frontier research field in entrepreneurship [5]. Some of scholars found that female entrepreneurs were less healthy than male entrepreneurs because they were affected more by working pressure [6], but others found argued that female entrepreneurs were less likely to suffer from cardiovascular disease than male entrepreneurs [7]. Meanwhile, some other empirical findings suggest no gender difference in health status of entrepreneurs $[8,9]$. The research of female entrepreneurs' health is deserved to be investigated.

Currently, scholars have examined the factors which would affect entrepreneurs' health. Some scholars found entrepreneurs were more likely to resist the positive effects of health $[10,11]$. On the other hand, aggressive and hostile entrepreneurs were opted to suffer more health problems $[8,12]$.

In addition, the uniqueness of entrepreneurship as a career choice also impacts on entrepreneurs' health conditions. Many studies find that as entrepreneurial practices proceed, entrepreneurs will face stress from several aspects such as market uncertainty [13] and financial uncertainty [14], and then sacrifice personal health. From another perspective, entrepreneurship also has advantages for health: the fact that entrepreneurs enjoy great autonomy and gain psychological benefits by being their own bosses is good for health [15]. The pressure starts when they choose to launch a business and become entrepreneurs [16]. Because they not only have to be responsible for the strategy, action, and success of a company but also have to take care of satisfying their shareholders, friends and families [10]. Entrepreneurial pressure would lead to entrepreneurs with anxiety and deep depression, and bad physical health [10].

Compared to male entrepreneurs, female entrepreneurs may hold lower entrepreneurial intention [17], report lower opportunity evaluation [18], and have more difficulties to obtain entrepreneurial finance [19]. Female entrepreneurs are suffering the negative stereotype threat because they are not consistent with the feminine social role [20-23]. This stereotype threat will bring lots of symptoms, such as increases in arterial blood pressure [24], heart rate variability [25], electroencephalogram [20], cardiovascular arousal [26]. These symptoms are belonging to physical health. Physical health refers to the physiologic and physical status of the body [27].

There are still some research gaps of current studies. First, persistence is vital for entrepreneurs to achieve success [28]. There exists sex differences in entrepreneurship [29]. Scholars have not discussed whether female entrepreneurs' persistence can help them to maintain health. Second, scholars have verified the entrepreneurial experience significantly influence entrepreneurs' psychological well-being [16]. However, scholars neglected that entrepreneurial experience as a persistence identity would also influence entrepreneurs' physical health. Third, firm age is a survival duration variable [30]. It also represents a persistence identity for firms. The existing research lacks the analysis of the impact of enterprise characteristics on the health of female entrepreneurs. Fourth, the physical health of entrepreneurs is neglected by scholars in entrepreneurship [31], especially for female entrepreneurs. Thus, we just focus on how persistence identity influence female entrepreneurs' physical health in this paper.

Our paper uses stereotype threat theory to explain which factors would be beneficial to female entrepreneurs' physical health. We find that female entrepreneurs activate the identity of experienced entrepreneurs as they have much more entrepreneurial experience and activate the identity of successful entrepreneurs as the firm age increasing. These positive identities are helpful for female entrepreneurs to overcome gender stereotype threat and maintain good health.

\section{Theory and hypothesis}

\section{Gender stereotype threat in entrepreneurship}

Gender stereotypes reflect shared beliefs about specific characteristics of men and women; for example, men perform better than in math than women [17, 32, 33]. In the business world, women find themselves in a stigmatized group as well [34]. The entrepreneur role is often characterized as bold, risk-taking, and aggressive [18]. Men are regarded as more agentic, and women are regarded as more communal $[35,36]$. Entrepreneurs are thought to have more masculine than feminine characteristics [22]. Thus, female entrepreneurs suffer from stereotype threat because female entrepreneurs are not consistent with feminine perceived social role, which leads to negative judgment [20-23]. The stereotypes they faced may create a disruptive state that undermines women's professional performance and aspirations [37]. When stereotypes 
have a negative impact on groups, it is called stereotype threat [38].

The Covid-19 pandemic challenges people's life [4]. Due to the virus spread rapidly, governors gave the "stayat-home" orders to try to slow down the spread [39]. The Covid-19 pandemic lockdown changed the world people are living in. Females are considered to put much time into taking care of their family, especially their children, not their career. Thus, female entrepreneurs suffered more gender stereotype threats under the pandemic context [40].

Gender stereotype threat can negatively influence the entrepreneurial process for women [33, 41]. Additionally, stereotype threat can affect biological factors [42]. Stereotype threat could cause a series of neurobiological consequences, such as increasing in arterial blood pressure [24], heart rate variability [25], and cardiovascular arousal [26], as well as causing stress due to unfair expectations [20, 24]. Thus, female entrepreneurs expose to stereotype threat might experience negative health consequences [37].

\section{Intervening in stereotype threat}

Stereotype threat intervention is a valuable way to help individuals get over stereotype threat [38]. Previous psychological literature has shown that holding a positive personal identity helps distinguish oneself from the stereotyped group [43, 44]. Identities are ongoing projects arising from dialogues between an inner self and an external discourse reflecting the social domain [22].

When women do not perceive themselves to be targeted by stereotypes, they may avoid stereotype threat $[43,44]$. When female entrepreneurs have more entrepreneurial experience, they become more confident and regard themselves as experienced entrepreneurs [22]. As firms established by female entrepreneurs grow older, their founders believe in themselves more and consider themselves successful entrepreneurs [45, 46]. Female entrepreneurs who establish a positive identity may avoid stereotype threat, leading to a better health status.

\section{The influence of entrepreneurial experience}

Generally, entrepreneurship is considered as an agentic activity $[18,47]$. However, as entrepreneurial experience increases, female entrepreneurs can obtain transferable skills and competencies from previous start-up experiences [22]. Prior start-up experience is defined as an individual's past experience relating to previous creation or founding of new business ventures [16]. Experienced entrepreneur sends the signals to external stakeholders that female entrepreneurs are credible and capable in entrepreneurial activities [48-50]. External stakeholders may believe in female entrepreneurs' ability rather than continuing undervaluing the role of female entrepreneur due to gender stereotype [33]. Consequently, when female entrepreneurs are labeled as experienced entrepreneurs, they can build this positive identity which can effectively eliminate the stereotype threat faced by female entrepreneurs.

When female entrepreneurs become serial entrepreneurs, it shows that they have self-evaluated as a "capable entrepreneur". Such women can also learn from failure and apply their knowledge to current business practices [51]. Only those entrepreneurs who believe that they are smart enough will start businesses again after failure [52]. Even though female entrepreneurs have experienced stereotype threat in past entrepreneurial activities, the success of those activities, which turns out to be a psychological self-affirmation may help them overcome stereotype threat [53].

Thus, with the entrepreneurial experiences increasing, women can identify as experienced entrepreneurs, which in turn can improve their health. The following hypothesis is therefore proposed:

H1 Among female entrepreneurs, the previous entrepreneurial experiences are positively related to their physical health.

\section{The influence of firm age}

Firm age can be regarded as the firm experience which gains from the entrepreneurial activities [54]. Aged firm is beneficial to reduce gender stereotype threat as well. Increased firm age is an important indicator to measure whether a firm is successful [46]. Because start-ups come with higher risks, many new ventures unfortunately end in failure [52, 55]. As firm age increases, the likelihood of entrepreneurial failure decreases $[55,56]$. Female entrepreneurs in such firms are then regarded as successful entrepreneurs.

Female entrepreneurs also acquire greater knowledge about how to manage a successful business during the process of entrepreneurship [57]. This process teaches women to compete and survive in their industry [46]. When female entrepreneurs are able to identify themselves as people with multiple positive traits, they are less susceptible to gender stereotype threat [44].

Therefore, due to firm age growth, women can identify themselves as successful entrepreneurs, thus they are better able to cope with stereotype threat and become heathier. The following hypothesis is therefore proposed: 


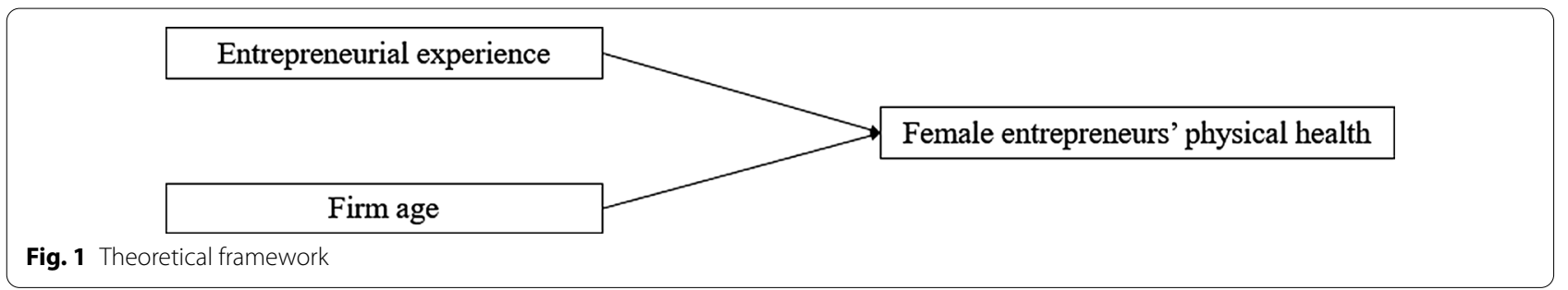

H2 Among female entrepreneurs, firm age is positively related to their physical health.

Thus, we showed the theoretical framework in Fig. 1.

\section{Methods}

\section{Data collection and sample}

We used the survey method to obtain data for Chinses entrepreneurs by questionnaire in Bohai Economic Rim $[58,59]$. We collected our sample and data in Bohai Economic Rim, including Beijing, Tianjin, province of Shandong, Hebei and Liaoning. The reason to choose this area is that Bohai Economic Rim is one of the most developed areas for entrepreneurial activities in China, and new ventures are more concentrated in this area [58]. We surveyed via face-to-face interviews in these areas where there are many small businesses. We conducted the first survey in 2015 and obtained 1021 questionnaires. Three hundred twenty-one entrepreneurs in the area had not been contacted or were unwilling to participate in our second face-to-face investigation. We got 700 questionnaires back in the second survey in 2016. The distribution of the industries in the 700 samples is scattered. The percentage of ventures in the manufacturing industry is $67.43 \%$, which is the highest. To ensure the validity of our research, we focused on the entrepreneurs who had founded a business in the manufacturing industry. Based on the industrial classification for national economic activities of the National Bureau of Statistics of China, the manufacturing industry refers to new products that have undergone physical or chemical changes. They are manufactured by machinery or by hand, and some products are manufactured in wholesale or retail. It includes the agricultural and sideline food processing industry, the food manufacturing industry, the textile industry, and so on. ${ }^{4}$ Besides, the development of manufacturing industry is important for local economics [60]. Thus, entrepreneurs in this field commonly face greater mental pressure, and they are suitable samples for an entrepreneurial health study. And then, we exclude the establishment of enterprise samples for more than 8 years to meet the

\footnotetext{
${ }^{4}$ For more subdivisions of the manufacturing industry, please refer to the National Bureau of Statistics of China's regulations. http://www.stats.gov.cn/ tjsj/tjbz/201301/t20130114_8675.html.
}

characteristics of a start-up [61]. We also eliminate invalid samples with missing values, and obtained 300 samples. Finally, a female sample of 114 are selected from this 300 samples pool.

As shown in Table 1, the age of these female entrepreneurs is ranging from 28 to 55 years. Almost all of the participants completed high school or technical secondary school degrees. The samples are evenly distributed among the five cities and provinces in the Bohai Economic Rim. As for industry, the number of start-ups engaged in food manufacturing, clothing, shoe and hat industry and art products manufacturing is larger than those of start-ups in the other divisions of manufacturing industry. Additionally, the average number of previous startups of these female entrepreneurs is 0.72 , and the average firm age is 5.16 years.

\section{Measures}

Independent variables: Entrepreneurial experience. The respondents' entrepreneurial experience was primarily measured by the survey question, "How many times have you started a business before this start-up?" Firm age. This variable was assessed by deducting from 2016 the number of years since their enterprises were established.

Dependent variables: Physical health. The researchers used headaches as the most important variable to study the health of entrepreneurs. As an important indicator of personal health, headache is the most frequent complaint in people's daily lives [62], and it may cause more physical and mental health problems [63]. Therefore, headaches can be used as a representative indicator to measure the physical health of entrepreneurs. Among the respondents, those who had had a headache were regarded as unhealthy and were marked with a 0 , and those who had not had a headache were regarded as healthy and marked with a 1 .

Control variables: Entrepreneurs' personal characteristics and the performance of start-ups might affect entrepreneurs' health $[7,64]$, our research controlled for several individual and firm-level variables. In individual level, this paper controlled for the age of entrepreneurs 
Table 1 Descriptive statistic

\begin{tabular}{|c|c|c|c|c|c|}
\hline & Sample characteristics & Freq & & Sample characteristics & Frequency \\
\hline Age & $28-30$ & 11 & Region & Beijing & 34 \\
\hline & $31-40$ & 48 & & Tianjin & 26 \\
\hline & $41-50$ & 48 & & Hebei & 16 \\
\hline & $51-55$ & 7 & & Shandong & 24 \\
\hline Education & Middle school & 3 & & Liaoning & 14 \\
\hline & High school & 36 & Child & Have child & 96 \\
\hline & Junior college & 47 & & No child & 18 \\
\hline & University & 28 & Industry & Food manufacturing & 16 \\
\hline Marriage & Unmarried & 6 & & Clothing, shoe and hat manufacturing & 18 \\
\hline & Married & 93 & & Art products manufacturing & 10 \\
\hline & Divorce & 15 & & Other manufacturing & 70 \\
\hline & & & & Standard deviation & Median \\
\hline Number of & us startups & & & 0.507 & 1.00 \\
\hline Firm age & & & & 2.127 & 5.50 \\
\hline Total numb & imples & & & 114 & \\
\hline
\end{tabular}

Data source calculated and sorted out by authors

and educational attainment [33]. The age of entrepreneurs was obtained by the number of years old and the educational attainment was obtained by the highest degree (primary $\operatorname{school}=1$, secondary high $\operatorname{school}=2$, senior high school/technical secondary school $=3$, junior college $=4$, undergraduate $=5$, graduate $=6$, Ph.D. $=7$, other $=8$ ). We also controlled for the marital status (married and divorced $=1$; single $=0$ ) and child [15]. The variable of child was measured by asking whether they had a child (yes $=1$, no $=0$ ). In addition, we controlled for the lifestyle of the participants [65]. The variable of lifestyle was measured by asking, "Do you do exercise frequently?" (yes $=1$, no $=0$ ). At the firm level, we controlled for industry category, firm size and sales growth rate. Based on industrial classification for national economic activities of the National Bureau of Statistics of China, there are thirties subdivisions of the manufacturing industry. We had controlled for the sub-industries in manufacturing. From the results of the descriptive statistics, we found that the samples in the food manufacturing industry, clothing, shoe, and hat manufacturing industry, and art products manufacturing industry are more than other sub-industries. We formed the dummy variables by defining whether the firms are in these three sub-industries. If yes, we coded as 1 ; if no, we coded as 0 . We also formed a new dummy variable named other industries. It means the firms are not in neither of these three sub-industries. Firm size was measured by taking the natural logarithm of the total assets of the company in 2016. Sales was measured by asking the participants the average sales growth rate in 2016.

\section{Results}

\section{Descriptive statistics and correlations}

The descriptive statistics and the correlation coefficient matrix of the variables are shown in Table 2 . The value of the variance inflation factors is all smaller than 2 . It means that the results are not needed to consider the multicollinearity concerns [59].

\section{Regression analysis}

In this paper, we used logistic regression for the analysis. We ran the regression by using SPSS 26.0. The results are shown in Table 3 . There was a Cox and Snell $\mathrm{R}^{2}$ increase from 0.093 (model 1) to 0.198 (model 2). The Nagelkerke $\mathrm{R}^{2}$ increased from 0.150 (model 1) to 0.323 (model 2). It suggests that the inclusion of the items of entrepreneurial experience and firm age greatly enhanced the explanatory degree of the models. The coefficient of the items of entrepreneurial experience and health status is positive and significant (model $2: \mathrm{b}=2.640, p=0.002$ ). The coefficient of the items of firm age and headache is also positive and significant (model $2: \mathrm{b}=0.271, p=0.088$ ). These results show that female entrepreneurs with more entrepreneurial experience are prone to be more health. When the firm age is larger, founders are prone to be more health. Hence, hypothesis 1 and hypothesis 2 are supported.

\section{Robustness checks}

To ensure the reliability of the conclusion, this study conducts one robustness tests by dividing 
Table 2 Correlation analysis

\begin{tabular}{|c|c|c|c|c|c|c|c|c|c|}
\hline & Mean & SD & 1 & 2 & 3 & 4 & 5 & 5 & 6 \\
\hline 1. Entrepreneurs age & 40.840 & 6.993 & 1.000 & & & & & & \\
\hline 2. Educational attainment & 3.880 & 0.811 & $-0.309^{* *}$ & 1.000 & & & & & \\
\hline 3. Marital status & 0.820 & 0.389 & -0.053 & -0.016 & 1.000 & & & & \\
\hline 4. Child & 0.840 & 0.366 & -0.127 & 0.113 & 0.167 & 1.0 & & & \\
\hline 5. Exercise & 0.740 & 0.442 & 0.001 & $0.230^{*}$ & 0.076 & 0.0 & & 1.000 & \\
\hline 6. Industry food manufacturing & 0.140 & 0.349 & -0.016 & -0.032 & -0.13 & 0.1 & & 0.127 & 1.000 \\
\hline 7. Industry clothing, shoe and hat manufacturing & 0.160 & 0.366 & 0.131 & $-0.202^{*}$ & 0.082 & 0.0 & & 0.040 & -0.175 \\
\hline 8. Industry art products manufacturing & 0.090 & 0.284 & -0.033 & 0.124 & 0.067 & 0.0 & & -0.026 & -0.125 \\
\hline 9. Firm size & 5.436 & 1.447 & 0.148 & 0.121 & $-0.04 C$ & 0.0 & & 0.100 & 0.007 \\
\hline 10. Sales growth rate & 14.680 & 10.762 & 0.068 & 0.115 & 0.02 & 0.1 & & 0.031 & 0.156 \\
\hline 11. Entrepreneurial experience & 0.720 & 0.507 & $0.562^{* *}$ & $-0.343^{* *}$ & 0.05 & -0.0 & & 0.062 & -0.126 \\
\hline 12. Firm age & 5.160 & 2.127 & 0.179 & 0.078 & -0.018 & 0.0 & & 0.176 & 0.161 \\
\hline \multirow[t]{2}{*}{ 13. Health status } & 0.816 & 0.389 & 0.038 & -0.128 & 0.066 & -0.08 & & -0.078 & -0.069 \\
\hline & Mean & SD & 7 & 8 & 9 & 10 & 11 & 12 & 13 \\
\hline 1. Entrepreneurs age & 40.840 & 6.993 & & & & & & & \\
\hline 2. Educational attainment & 3.880 & 0.811 & & & & & & & \\
\hline 3. Marital status & 0.820 & 0.389 & & & & & & & \\
\hline 4. Child & 0.840 & 0.366 & & & & & & & \\
\hline 5. Exercise & 0.740 & 0.442 & & & & & & & \\
\hline 6. Industry food manufacturing & 0.140 & 0.349 & & & & & & & \\
\hline 7. Industry clothing, shoe and hat manufacturing & 0.160 & 0.366 & 1.000 & & & & & & \\
\hline 8. Industry art products manufacturing & 0.090 & 0.284 & -0.134 & 1.000 & & & & & \\
\hline 9. Firm size & 5.436 & 1.447 & 0.087 & -0.101 & 1.000 & & & & \\
\hline 10. Sales growth rate & 14.680 & 10.762 & -0.012 & -0.118 & $0.599^{* *}$ & 1.000 & & & \\
\hline 11. Entrepreneurial experience & 0.720 & 0.507 & 0.146 & $-0.196^{*}$ & 0.110 & -0.046 & 1.000 & & \\
\hline 12. Firm age & 5.160 & 2.127 & -0.010 & 0.006 & $0.359^{* *}$ & $0.310^{* *}$ & 0.000 & 1.000 & \\
\hline 13. Health status & 0.816 & 0.389 & 0.020 & $-0.253^{* *}$ & -0.032 & -0.092 & $0.319^{* *}$ & 0.057 & 1.000 \\
\hline
\end{tabular}

Data source calculated and sorted out by authors

*Means $p<0.05$, ${ }^{* *}$ means $p<0.01$, two-tailed test

entrepreneurial experience into two groups according to whether they have entrepreneurial experience (yes $=1$, no $=0$ ) and dividing firm ages into two groups according to median firm age, which is 5.50 years old: above or equal to 6 years old $=1$ and under 6 years old $=0$. Table 4 shows that the Cox and Snell $R^{2}$ increases from 0.093 (model 3) to 0.212 (model 4). The Nagelkerke $R^{2}$ increases from 0.150 (model 3) to 0.345 (model 4). This indicates that the items of entrepreneurial experience and firm age are contribute to the models. The coefficients of the entrepreneurial experience and health status is positive and significant (model 4: $\mathrm{b}=2.864, p=0.001$ ). The coefficients of the firm age and health status is also positive and significant (model $4: \mathrm{b}=1.685 p=0.027$ ).

It seems that entrepreneurial experience and firm age are very robust variables. Hence, hypothesis 1 and hypothesis 2 of this paper are also supported. Thus, the results of this research are reliable and robust.

This paper also uses the male sample to verify the relationship between these two independent variables and health status (see Additional file 1). We find no similar results, so it can be proved that gender stereotype threat only exists in the group of female entrepreneurs.

\section{Conclusion and discussion}

The Covid-19 pandemic leads small businesses to face a more uncertain business environment [3]. People might face unemployment stress [66] or infection-related stressors [67]. Female entrepreneurs are also faced with stereotype threat stress [40]. Female entrepreneurs should build a positive identity to get over the stereotype threat under the Covid-19 pandemic context. Based on stereotype threat theory, this paper used 2-year entrepreneurs' tracking data from China's Bohai Economic Rim to 
Table 3 Logistic regression results

\begin{tabular}{|c|c|c|}
\hline Variable & Model 1 & Model 2 \\
\hline Constant & $\begin{array}{l}3.429 \\
(1.463)\end{array}$ & $\begin{array}{l}6.287^{*} \\
(3.292)\end{array}$ \\
\hline Entrepreneur age & $\begin{array}{l}-0.003 \\
(0.007)\end{array}$ & $\begin{array}{l}-0.117^{* *} \\
(4.290)\end{array}$ \\
\hline Educational attainment & $\begin{array}{l}-0.262 \\
(0.489)\end{array}$ & $\begin{array}{l}-0.168 \\
(0.158)\end{array}$ \\
\hline Marital status & $\begin{array}{l}0.645 \\
(0.997)\end{array}$ & $\begin{array}{l}0.402 \\
(0.308)\end{array}$ \\
\hline Child & $\begin{array}{l}-0.573 \\
(0.401)\end{array}$ & $\begin{array}{l}-0.428 \\
(0.210)\end{array}$ \\
\hline Lifestyle & $\begin{array}{l}-0.405 \\
(0.368)\end{array}$ & $\begin{array}{l}-0.917 \\
(1.505)\end{array}$ \\
\hline Industry food manufacturing & $\begin{array}{l}-0.520 \\
(0.495)\end{array}$ & $\begin{array}{l}-0.345 \\
(0.156)\end{array}$ \\
\hline $\begin{array}{l}\text { Industry clothing, shoes and hats manufactur- } \\
\text { ing }\end{array}$ & $\begin{array}{l}-0.400 \\
(0.270)\end{array}$ & $\begin{array}{l}-0.697 \\
(0.712)\end{array}$ \\
\hline Industry art products manufacturing & $\begin{array}{l}-2.010^{* * *} \\
(6.869)\end{array}$ & $\begin{array}{l}-1.736^{* *} \\
(4.096)\end{array}$ \\
\hline Firm size & $\begin{array}{l}0.066 \\
(0.087)\end{array}$ & $\begin{array}{l}-0.169 \\
(0.443)\end{array}$ \\
\hline Sales growth rate & $\begin{array}{l}-0.028 \\
(0.840)\end{array}$ & $\begin{array}{l}-0.017 \\
(0.253)\end{array}$ \\
\hline Entrepreneurial experience & & $\begin{array}{l}2.640^{* * *} \\
(9.820)\end{array}$ \\
\hline Firm age & & $\begin{array}{l}0.271^{*} \\
(2.908)\end{array}$ \\
\hline Cox and Snell R-square & 0.093 & 0.198 \\
\hline Nagelkerke R-square & 0.150 & 0.323 \\
\hline
\end{tabular}

The number in the parenthesis are the results from Wald-Test

Data source calculated and sorted out by authors

${ }^{*}$ Means $p<0.1,{ }^{* *}$ means $p<0.05,{ }^{* * *}$ means $p<0.01$, two-tailed test

verify that the increase in entrepreneurial experience and the growth of a company's age could help female entrepreneurs to maintain good health.

\section{Theoretical implications}

The findings of the paper support the core argument that entrepreneurs' experience and firm age will help female entrepreneurs maintain health. Previous research mainly examined how entrepreneurs' personality (individual level) and entrepreneurial occupation (organizational level) influenced individuals' health. However, less work had been conducted about how external dynamics factors affected female entrepreneurs' health. Our research introduces two dynamic variables into the research of entrepreneur health: entrepreneurial experience (individual level) and firm age (organizational level). Our paper finds that these two variables can affect the health of female entrepreneurs, extending the research scope of previous studies.

In addition, this paper contributes to the study of female entrepreneurship. The previous psychological
Table 4 Logistic regression results of robust test

\begin{tabular}{|c|c|c|}
\hline Variable & Model 3 & Model 4 \\
\hline Constant & $\begin{array}{l}3.429 \\
(1.463)\end{array}$ & $\begin{array}{l}7.739^{* *} \\
(4.297)\end{array}$ \\
\hline Entrepreneur age & $\begin{array}{l}-0.003 \\
(0.007)\end{array}$ & $\begin{array}{l}-0.130^{* *} \\
(4.785)\end{array}$ \\
\hline Educational attainment & $\begin{array}{l}-0.262 \\
(0.489)\end{array}$ & $\begin{array}{l}-0.163 \\
(0.140)\end{array}$ \\
\hline Marital status & $\begin{array}{l}0.645 \\
(0.997)\end{array}$ & $\begin{array}{l}0.577 \\
(0.591)\end{array}$ \\
\hline Child & $\begin{array}{l}-0.573 \\
(0.401)\end{array}$ & $\begin{array}{l}-0.253 \\
(0.069)\end{array}$ \\
\hline Lifestyle & $\begin{array}{l}-0.405 \\
(0.368)\end{array}$ & $\begin{array}{l}-0.993 \\
(1.720)\end{array}$ \\
\hline Industry food manufacturing & $\begin{array}{l}-0.520 \\
(0.495)\end{array}$ & $\begin{array}{l}-0.539 \\
(0.375)\end{array}$ \\
\hline $\begin{array}{l}\text { Industry clothing, shoes and hats manufactur- } \\
\text { ing }\end{array}$ & $\begin{array}{l}-0.400 \\
(0.270)\end{array}$ & $\begin{array}{l}-0.935 \\
(1.209)\end{array}$ \\
\hline Industry art products manufacturing & $\begin{array}{l}-2.010^{* * *} \\
(6.869)\end{array}$ & $\begin{array}{l}-2.065^{* *} \\
(4.933)\end{array}$ \\
\hline Firm size & $\begin{array}{l}0.066 \\
(0.087)\end{array}$ & $\begin{array}{l}-0.266 \\
(1.007)\end{array}$ \\
\hline Sales growth rate & $\begin{array}{l}-0.028 \\
(0.840)\end{array}$ & $\begin{array}{l}-0.019 \\
(0.304)\end{array}$ \\
\hline Entrepreneurial experience & & $\begin{array}{l}2.864^{* * *} \\
(10.394)\end{array}$ \\
\hline Firm age & & $\begin{array}{l}1.685^{* *} \\
(4.914)\end{array}$ \\
\hline Cox and Snell R-square & 0.093 & 0.212 \\
\hline Nagelkerke R-square & 0.150 & 0.345 \\
\hline
\end{tabular}

The number in the parenthesis are the results from Wald-Test

Data source calculated and sorted out by authors

** means $p<0.05,{ }^{* * *}$ means $p<0.01$, two-tailed test

research had examined that stereotype threat did have a negative impact on individuals' health [24-26]. During the process of entrepreneurship, female entrepreneurs are facing gender stereotype threat, while male entrepreneurs do not. However, women can reduce gender stereotype threat by establishing multiple positive personal identities [44] through entrepreneurial history. Using the sample of female entrepreneurs from China, this paper posits that increasing entrepreneurial experience and growing firm age may help women establish positive identity, which is an effective way to overcome gender stereotype threat, and thus may benefit to female entrepreneur's health. This paper describes the factors affect the health of female entrepreneurs, enriching the research framework for female entrepreneurship.

\section{Practical implications}

When people become entrepreneurs, they may endure greater stress than ordinary people. This could be worse for female entrepreneurs, as they may have to pay more 
efforts to balance work and family or to cope with stereotype threat in workplaces. Our paper suggests that persist in what they are doing may help female entrepreneurs maintain health. Social media can report more positive female entrepreneurs' models and emphasize that females are qualified or even more suitable for entrepreneurship.

Secondly, this paper gives the practical implication from the policy perspective. This article finds that female entrepreneurs are more likely to be unhealthier in the art products manufacturing. Policymakers should increase paying attention to female entrepreneurs in art products manufacturing industry. We suggest that local government and business incubation centers appropriately organize training and exhibitions to help female entrepreneurs improve their entrepreneurial skills and broaden their visions. By helping female entrepreneurs to establish an experienced identity, it helps female entrepreneurs to keep healthy.

Additionally, the government should give female entrepreneurs more support in the early stage of entrepreneurship. Compared with mature companies, younger companies may encounter more difficulties. The government can help female entrepreneurs through the challenging early-stage by reducing taxes, reducing loan interest rates, and helping them obtain financing. the support of government policies can effectively limit the higher firm failure rate during the early years. A benign entrepreneurial environment is beneficial to female entrepreneurs to achieve their goals. Then, it helps them establish a successful identity, which improves the health of female entrepreneurs.

Lastly, we provide practical implications for governments and female entrepreneurs during the pandemic. Female entrepreneurs are suffering tremendous pressure in the pandemic. This hostile environment would challenge the health status of female entrepreneurs. On the one side of the results of this paper, the entrepreneurial experience could help female entrepreneurs keep healthy. The government should encourage female entrepreneurs who close their businesses forever during the Pandemic to reestablish a new one. On the other side of the results of this paper, firm age could help female entrepreneurs keep healthy. If the firms insist on opening during the pandemic, it might benefit female entrepreneurs' health.

\section{Supplementary Information}

The online version contains supplementary material available at https://doi. org/10.1186/s12905-021-01471-6.

Additional file 1. Logistic Regression Results for the sample of male entrepreneurs.

\section{Authors' contributions}

Jia and Xu conceptualized study design, and contributed to manuscript writing. Lin and Jiang collected data and did the statistical analysis. Jia and Xu wrote the draft and Lin and Jiang revised the manuscript. The same contribution to this paper for each author. All authors read and approved the final manuscript.

\section{Funding}

National Natural Science Foundation of China (Grant No. 72072192).

\section{Availability of data and materials}

The datasets used and/or analyzed during the current study are available from the corresponding author upon reasonable request.

\section{Declarations}

\section{Ethics approval and consent to participate}

Ethics approval for this study was obtained from the Central University of Finance and Economics, Academic Committee of Business School (HC20180901). The entrepreneurs provided the informed consent when they filled in the questionnaire. Administrative permissions were not required to access and use the data described in this study. All methods were performed in accordance with the relevant guidelines and regulations (Declaration of Helsinki).

\section{Consent for publication}

Not applicable.

\section{Competing interests}

The authors declare that they have no competing interests.

\section{Author details}

${ }^{1}$ Business School, Central University of Finance and Economics, Beijing 100081, China. ${ }^{2}$ Business School, Beijing Technology and Business University, Beijing 100048, China.

Received: 22 March 2021 Accepted: 31 August 2021

Published online: 08 September 2021

\section{References}

1. Kuckertz A, Brändle L, Gaudig A, Hinderer S, Reyes CAM, Prochotta A, Steinbrink KM, Berger ESC. Startups in times of crisis - a rapid response to the COVID-19 pandemic. J Bus Ventur Insights. 2020;14:e00169.

2. Björklund TA, Mikkonen M, Mattila P, Marel FVD. Expanding entrepreneurial solution spaces in times of crisis: business model experimentation amongst packaged food and beverage ventures. J Bus Ventur Insights. 2020;14:e00197.

3. Patel PC, Rietveld CA. The impact of financial insecurity on the selfemployed's short-term psychological distress: evidence from the COVID19 pandemic. J Bus Ventur Insights. 2020;14:e00206.

4. Zahra D, Shahideh JS, Samaneh Y, Mahnaz BK, Anoshiravan K. Influential factors on quality of life in married Iranian women during the COVID-19 pandemic in 2020: a path analysis. BMC Women's Health. 2021;21:102.

5. Shir N, Nikolaev B, Wincent J. Entrepreneurship and well-being: the role of psychological autonomy, competence, and relatedness. J Bus Ventur. 2019;34(5):105875.

6. Parslow R, Jorm AF, Christensen H, Rodgers B, Strazdins L, Dsouza RM. The associations between work stress and mental health: a comparison of organizationally employed and self-employed workers. Work Stress. 2004;18(3):231-44.

7. Luoto R, Pekkanen J, Uutela A, Tuomilehto J. Cardiovascular risks and socioeconomic status: differences between men and women in Finland. J Epidemiol Community Health. 1994;48(4):348-54.

8. Buttner EH. Entrepreneurial stress: is it hazardous to your health? J Manag Issues. 1992:2:223-40.

9. Voltmer E, Spahn C, Schaarschmidt U, Kieschke U. Work-related behavior and experience patterns of entrepreneurs compared to teachers and physicians. Int Arch Occup Environ Health. 2011;84(5):479-900. 
10. Baron RA, Franklin RJ, Hmieleski KM. Why entrepreneurs often experience low, not high, levels of stress: the joint effects of selection and psychological capital. J Manag. 2016;42(3):742-68.

11. Rahim A. Stress, strain, and their moderators: an empirical comparison of entrepreneurs and managers. J Small Bus Manag. 1996;34(1):46-58.

12. Boyd DP, Webb RJ. The coronary costs of choosing a small business career. Am J Small Bus. 1982;6(4):3-9.

13. Yoon J, Bernell S. The effect of self-employment on health, access to care, and health behavior. Health. 2013;5(12):2116-27.

14. Dahl MS, Nielsen J, Mojtabai R. The effects of becoming an entrepreneur on the use of psychotropics among entrepreneurs and their spouses. Scand J Public Health. 2010;38(8):857-63.

15. Nikolova M. Switching to self-employment can be good for your health. J Bus Ventur. 2019;34(4):664-91.

16. Uy MA, Der Foo M, Song Z. Joint effects of prior start-up experience and coping strategies on entrepreneurs psychological well-being. J Bus Ventur. 2013;28(5):583-97.

17. Gupta VK, Turban DB, Bhawe NM. The effect of gender stereotype activation on entrepreneurial intentions. J Appl Psychol. 2008;93(5):1053-61.

18. Gupta VK, Goktan AB, Gunay G. Gender differences in evaluation of new business opportunity: a stereotype threat perspective. J Bus Ventur. 2014;29(2):273-88.

19. Buttner $E H$, Rosen B. Funding new business ventures: are decision makers biased against women entrepreneurs? J Bus Ventur. 1989;4(4):249-61.

20. Inzlicht M, Kang SK. Stereotype threat spillover: how coping with threats to social identity affects aggression, eating, decision making, and attention. J Pers Soc Psychol. 2010;99(3):467-81.

21. Levy DJ, Heissel JA, Richeson JA, Adam EK. Psychological and biological responses to race-based social stress as pathways to disparities in educational outcomes. Am Psychol. 2016;71(6):455-73.

22. Marlow S, Mcadam M. Incubation or induction? Gendered identity work in the context of technology business incubation. Entrep Theory Pract. 2015;39(4):791-816.

23. Steele CM, Aronson J. Stereotype threat and the intellectual test performance of African Americans. J Pers Soc Psychol. 1995;69(5):797-811.

24. Blascovich J, Spencer SJ, Quinn DM, Steele CM. African Americans and high blood pressure: the role of stereotype threat. Psychol Sci. 2001;12(3):225-9.

25. Croizet J, Despres G, Gauzins M, Huguet P, Leyens J, Meot A. Stereotype threat undermines intellectual performance by triggering a disruptive mental load. Pers Soc Psychol B. 2004;30(6):721-31.

26. Vick SB, Seery MD, Blascovich J, Weisbuch M. The effect of gender stereotype activation on challenge and threat motivational states. J Exp Soc Psychol. 2008:44(3):624-30.

27. Ware JE, Brook RH, Davies AR, Lohr KN. Choosing measures of health status for individuals in general populations. Am J Public Health. 1981;71(6):620-5.

28. Gompers P, Kovner A, Lerner J, Scharfstein D. Performance persistence in entrepreneurship. J Financ Econ. 2010;96:18-32.

29. Hatak I, Zhou HB. Health as human capital in entrepreneurship: Individual, extension, and substitution effects on entrepreneurial success. Entrep Theory Pract. 2021;45(1):18-42.

30. Delmar F, Shane S. Legitimating first: organizing activities and the survival of new ventures. J Bus Ventur. 2004;19(3):385-410.

31. Patel PC, Wolfe MT. Under pressure: the effect of antioxidants on health consequences related to oxidative stress. Entrep Theory Pract. 2021:45(1):211-41.

32. Gupta VK, Turban DB, Wasti SA, Sikdar A. The role of gender stereotypes in perceptions of entrepreneurs and intentions to become an entrepreneur. Entrep Theory Pract. 2009;33(2):397-417.

33. Hmieleski KM, Sheppard LD. The Yin and Yang of entrepreneurship: gender differences in the importance of communal and agentic characteristics for entrepreneurs'subjective well-being and performance. J Bus Ventur. 2019:34(4):709-30.

34. Koenig AM, Eagly AH. Evidence for the social role theory of stereotype content: observations of groups' roles shape stereotypes. J Pers Soc Psychol. 2014;107(3):371-92.

35. Eagly AH, Wood W. Explaining sex differences in social behavior: a metaanalytic perspective. Pers Soc Psychol B. 1991;17(3):306-15.
36. Franke GR, Crown DF, Spake DF. Gender differences in ethical perceptions of business practices: a social role theory perspective. J Appl Psychol. 1997;82(6):920-34.

37. Spencer SJ, Logel C, Davies PG. Stereotype threat. Annu Rev Psychol. 2016;67:415-37.

38. Liu S, Liu P, Wang M, Zhang B. Effectiveness of stereotype threat interventions: a meta-analytic review. J Appl Psychol. 2021;106(6):921-49.

39. Sergent K, Stajkovic AD. Women's leadership is associated with fewer deaths during the COVID-19 crisis: quantitative and qualitative analyses of united states governors. J Appl Psychol. 2021;105(8):771-83.

40. Rosenfeld DL, Tomiyama AJ. Can a pandemic make people more socially conservative? Political ideology, gender roles, and the case of COVID-19. J Appl Soc Psychol. 2021;54(4:)425-33.

41. Picho K, Schmader T. When do gender stereotypes impair math performance? A study of stereotype threat among Ugandan Adolescents. Sex Roles. 2018;78:295-306.

42. Johnson MA, Stevenson RM, Letwin CR. A woman's place is in the... startup! Crowdfunder judgments, implicit bias, and the stereotype content model. J Bus Ventur. 2018;33(6):813-31.

43. Hippel CV, Issa M, Ma R, Stokes A. Stereotype threat: antecedents and consequences for working women. Eur J Soc Psychol. 2011;41(2):151-61.

44. Rydell RJ, Mcconnell AR, Beilock SL. Multiple social identities and stereotype threat: imbalance, accessibility, and working memory. J Pers Soc Psychol. 2009;96(5):949-66.

45. Gjerlovjuel P, Guenther C. Early employment expansion and long-run survival: examining employee turnover as a context factor. J Bus Ventur. 2019;34(1):80-102.

46. Pe'er A, Vertinsky I, Keil T. Growth and survival: the moderating effects of local agglomeration and local market structure. Strateg Manag J. 2016;37(3):541-64.

47. Eddleston KA, Powell GN. The role of gender identity in explaining sex differences in business owners' career satisfier preferences. J Bus Ventur. 2008:23(2):244-56.

48. Murphy PJ, Kickul J, Barbosa SD, Titus L. Expert capital and perceived legitimacy: female-run entrepreneurial venture signaling and performance. Int J Entrep Innov. 2007;8(2):127-38.

49. Nagy BG, Pollack JM, Rutherford MW, Lohrke FT. The influence of entrepreneurs' credentials and impression management behaviors on perceptions of new venture legitimacy. Entrep Theory Pract. 2012;36(5):941-65.

50. Tornikoski ET, Newbert SL. Exploring the determinants of organizational emergence: a legitimacy perspective. J Bus Ventur. 2007;22(2):311-35.

51. Simmons SA, Carr JC, Hsu DK, Shu C. The regulatory fit of serial entrepreneurship intentions. Appl Psychol. 2016;65(3):605-27.

52. Yamakawa Y, Peng MW, Deeds DL. Rising from the ashes: cognitive determinants of venture growth after entrepreneurial failure. Entrep Theory Pract. 2015;39(2):209-36.

53. Taillandier-Schmitt A, Esnard C, Mokounkolo R. Self-affirmation in occupational training: effects on the math performance of french women nurses under stereotype threat. Sex Roles. 2012;67(1-2):43-57.

54. Durand R, Coeurderoy R. Age, order of entry, strategic orientation, and organizational performance. J Bus Ventur. 2001;16(5):471-94.

55. Zimmerman MA, Zeitz G. Beyond survival: achieving new venture growth by building legitimacy. Acad Manag Rev. 2002;27(3):414-31.

56. Kalleberg AL, Leicht KT. Gender and organizational performance: determinants of small business survival and success. Acad Manag J. 1991;34(1):136-61.

57. Brüderl J, PreisendÖrfer P, Ziegler R. Survival chances of newly founded business organizations. Am Sociol Rev. 1992;57:227-42.

58. Eggers JP, Song L. Dealing with failure: Serial entrepreneurs and the costs of changing industries between ventures. Acad Manag J. 2014;58:1785-803.

59. Liu Y, Li Y, Hao X, Zhang Y. Narcissism and learning from entrepreneurial failure. J Bus Ventur. 2019;34(3):496-512.

60. Quatraro F. Knowledge coherence, variety and economic growth: manufacturing evidence from Italian regions. Res Policy. 2010;39(10):1289-302.

61. Vaznyte $E$, Andries P. Entrepreneurial orientation and start-ups' external financing. J Bus Ventur. 2019;34(3):439-58.

62. Stewart WF, Ricci JA, Chee E, Morganstein D, Lipton RB. Lost productive time and cost due to common pain conditions in the us workforce. JAMA. 2003;290(18):2443-54. 
63. Yokoyama M, Yokoyama T, Funazu K, Yamashita T, Kondo S, Hosoai H, Yokoyama A, Nakamura H. Associations between headache and stress, alcohol drinking, exercise, sleep, and comorbid health conditions in a Japanese population. J Headache Pain. 2009;10(3):177-85.

64. Chao L, Pauly MV, Szrek H, Pereira N, Bundred F, Cross C, Gow J. Poor health kills small business: illness and microenterprises in South Africa. Health Affair. 2007;26(2):474-82.

65. Goldsby MG, Kuratko DF, Bishop JW. Entrepreneurship and fitness: an examination of rigorous exercise and goal attainment among small business owners. J Small Bus Manag. 2005;43(1):78-92.

66. Ployhart RE, Shepherd WJ, Strizver SD. The COVID-19 pandemic and new hire engagement: relationships with unemployment rates, state restrictions, and organizational tenure. J Appl Psychol. 2021;106(4):518-29.

67. Shao Y, Fang Y, Wang M, Chang C, Wang L. Making daily decisions to work from home or to work in the office: the impacts of daily work- and COVID-related stressors on next-day work location. J Appl Psychol. 2021;106(6):825-38.

\section{Publisher's Note}

Springer Nature remains neutral with regard to jurisdictional claims in published maps and institutional affiliations.
Ready to submit your research? Choose BMC and benefit from:

- fast, convenient online submission

- thorough peer review by experienced researchers in your field

- rapid publication on acceptance

- support for research data, including large and complex data types

- gold Open Access which fosters wider collaboration and increased citations

- maximum visibility for your research: over 100M website views per year

At BMC, research is always in progress.

Learn more biomedcentral.com/submissions 